\title{
A record of the Porbeagle, Lamna nasus, in coastal waters of Buenos Aires (Argentina) confirmed by DNA barcoding
}

DOI 10.1515/dna-2015-0017

Received February 27, 2015; accepted July 6, 2015

\begin{abstract}
A record of a juvenile Porbeagle, Lamna nasus, in the coastal waters of Argentina is confirmed by DNA barcoding, since the specimen lacked some external diagnostic features. We discuss the occurrence of this species in the coastal waters of Argentina, its molecular affinity with conspecifics from a broad range of the species, and relevant conservation issues.
\end{abstract}

Keywords: Lamna nasus, Porbeagle, shark, Argentina, Coastal waters, DNA barcode, Conservation.

On 29 May 2009, a juvenile male shark was found dead at Chapadmalal beach (Buenos Aires, Argentina) (38 $\left.11^{\prime} 46^{\prime \prime} \mathrm{S}, 57^{\circ} 40^{\prime} 19^{\prime \prime} \mathrm{W}\right)$. Surface water temperature during this week ranged from 13.6 to $13.8^{\circ} \mathrm{C}$. Unfortunately, the specimen lacked the head, but some external features identified it as belonging to the family Lamnidae. Moreover, its general body shape, the position of the first dorsal fin, a double caudal keel, and the white colour of the free rear tip of the first dorsal fin, suggested a

\footnotetext{
*Corresponding author: Ezequiel Mabragaña, Laboratorio de Biotaxonomía Morfológica y Molecular de Peces (BIMOPE), Instituto de Investigaciones Marinas y Costeras (IIMyC), Consejo Nacional de Investigaciones Científicas y Técnicas (CONICET), Facultad de Ciencias Exactas y Naturales, Universidad Nacional de Mar del Plata, Funes 3350, B7602AYL, Mar del Plata, Buenos Aires, Argentina, E-mail:emabraga@mdp.edu.ar

Juan M. Díaz de Astarloa, Laboratorio de Biotaxonomía Morfológica y Molecular de Peces (BIMOPE), Instituto de Investigaciones Marinas y Costeras (IIMyC), Consejo Nacional de Investigaciones Científicas y Técnicas (CONICET), Facultad de Ciencias Exactas y Naturales, Universidad Nacional de Mar del Plata, Funes 3350, B7602AYL, Mar del Plata, Buenos Aires, Argentina

Luis 0. Lucifora, Instituto de Biología Subtropical - Iguazú, CONICET, Universidad Nacional de Misiones, Casilla de Correo 9, N3370AVQ,

Puerto Iguazú, Misiones, Argentina
}

tentative identification as Lamna nasus (Bonnaterre, 1788). The specimen (without the head) measured $105 \mathrm{~cm}$, corresponding to a total length of about $130 \mathrm{~cm}$ (Figure 1).

In order to confirm the tentative morphological identification, a sample of muscle tissue was excised from the specimen for genetic analysis and preserved in $96 \%$ ethanol at $-20^{\circ} \mathrm{C}$. DNA extraction, polymerase chain reaction (PCR) and sequencing of cytochrome oxidase subunit I (COI) gene were performed following standard DNA barcoding methods [1] and a 652- basepair amplicon for the $5^{\prime}$ region of the mitochondrial COI gene was bidirectionally sequenced (Genbank accession number HM421926).

Using the library of sequences available on BOLD (Barcode of Life Data Systems), the closest matches to our DNA sequence were obtained. In addition, the relative placement of our sequence in the lineage cluster, or Barcode Index Number (BIN) assigned by BOLD, was assessed. The BIN system is "an online framework that clusters barcode sequences algorithmically, generating a web page for each cluster. Since clusters show high concordance with species, BINs can be used to verify species identifications as well as document diversity when taxonomic information is lacking" (see boldsystems.org and Ratnasingham and Hebert [2] for further details). In addition, the publically available COI sequences of Lamna spp. were downloaded and compared with the sequence from our specimen. Sequence divergences were calculated using the Kimura two parameter (K2P) distance model [3], and a Neighbor-joining (NJ) tree of K2P distances were created to provide graphic representations of divergence between specimens, using the software MEGA v5.0 [4]. The $\mathrm{NJ}$ tree was bootstrapped 500 times to provide percentage bootstrap values for branch points. Finally, we examined the COI sequences of the public records of Lamna nasus for diagnostic characters using MEGA v5.0.

When compared to the BOLD "Species Level Barcode Records" database, using the BOLD ID-engine (which includes every COI Barcode record with a species-level 


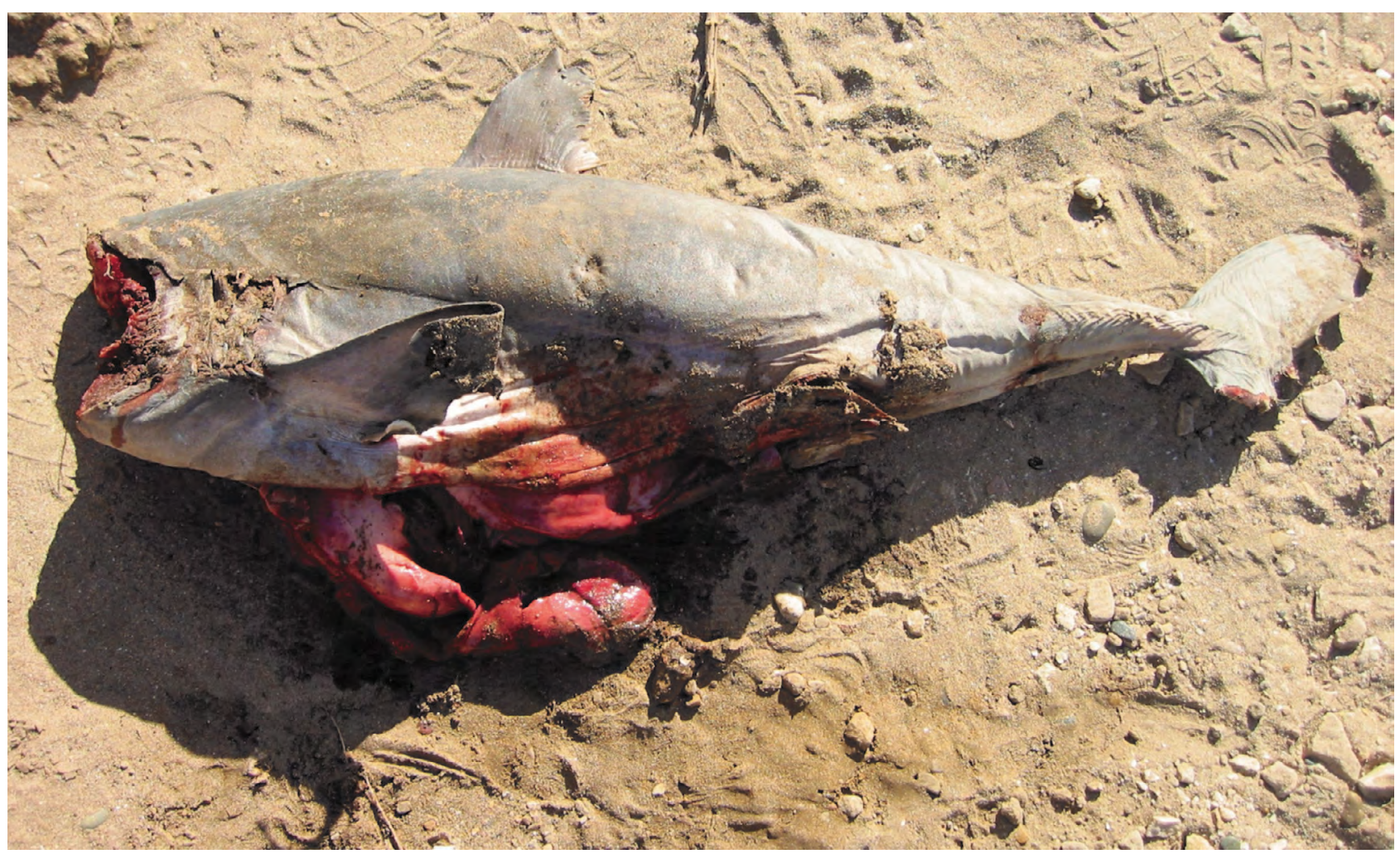

Figure 1. Specimen of Lamna nasus found at Chapadmalal beach (Argentina).

identification and a minimum sequence length of $500 \mathrm{bp}$ ), our specimen (UNMDP 1511/FARG 664-09) matched Lamna nasus with a similarity range of $98.62 \%-100 \%$ $(\mathrm{n}=99)$. The database contains specimens collected all over the world, including both the southern (SH) and northern hemisphere $(\mathrm{NH})$. All records fall into the same BIN, BOLD:AAA3577 (if there were different BINs within a set of specimens, putatively of the same species, it would indicate that specimens may represent different cryptic species, or there is unusually large genetic variation within a species, or, most commonly, there are misidentifications in the database).

The average K2P genetic distance between public records of Lamna nasus ( $\mathrm{n}=85$ ) was $0.84 \%$ and the maximum intraspecific distance was $1.71 \%$. The distance to the nearest neighbor was $5.47 \%$, which occupied a BIN with 18 members identified as Lamna ditropis (BOLD: AAC0516). Significant structuring in COI sequences was detected in our analysis of Lamna nasus using public records. Three main clusters of closely related haplotypes were found, one exclusively containing specimens from the $\mathrm{NH}$, and other two with specimens only from the SH (Fig. 2). No haplotypes are shared between specimens from the northern and southern hemispheres. The two SH clusters both contain specimens from South Africa, New Zealand, Chile and Argentina. Our specimen shares its haplotype with one of the two SH clusters, i.e. only with specimens from the SH. Our specimen UNMDP 1511 showed much lower K2P genetic distances (GD) from specimens collected in the SH that belong to the same cluster (GD $=0-0.15 \%$ ) than from those of the $\mathrm{NH}$ cluster (GD $=0.84-1.40 \%)$, or the second SH cluster (GD $=0.93-1.23 \%$ ). In addition, the structuring of COI sequences was also indicated by singlenucleotide diagnostic characters: each of the three groups contain unique diagnostic characters (Table 1).

The Porbeagle inhabits coastal and oceanic waters in temperate and cold-temperate waters worldwide. It is most abundant on the continental offshore fishing banks but is

Table 1. Nucleotic position for each diagnostic character in public records of Lamna nasus from Northern (NH) and Southern (SH) hemisphere.

\begin{tabular}{lllllllll}
\hline Groups/Nucleotic position & $\# 4$ & $\# 25$ & $\# 79$ & $\# 85$ & $\# 169$ & $\# 313$ & $\# 385$ & $\# 625$ \\
\hline $\mathrm{SH}_{1}$ & G & A & G & C & G & A & A & A \\
$\mathrm{SH}_{2}$ & G & A & A & T & A & G & G & G \\
$\mathrm{NH}$ & C & G & G & T & G & G & G & G \\
\hline
\end{tabular}




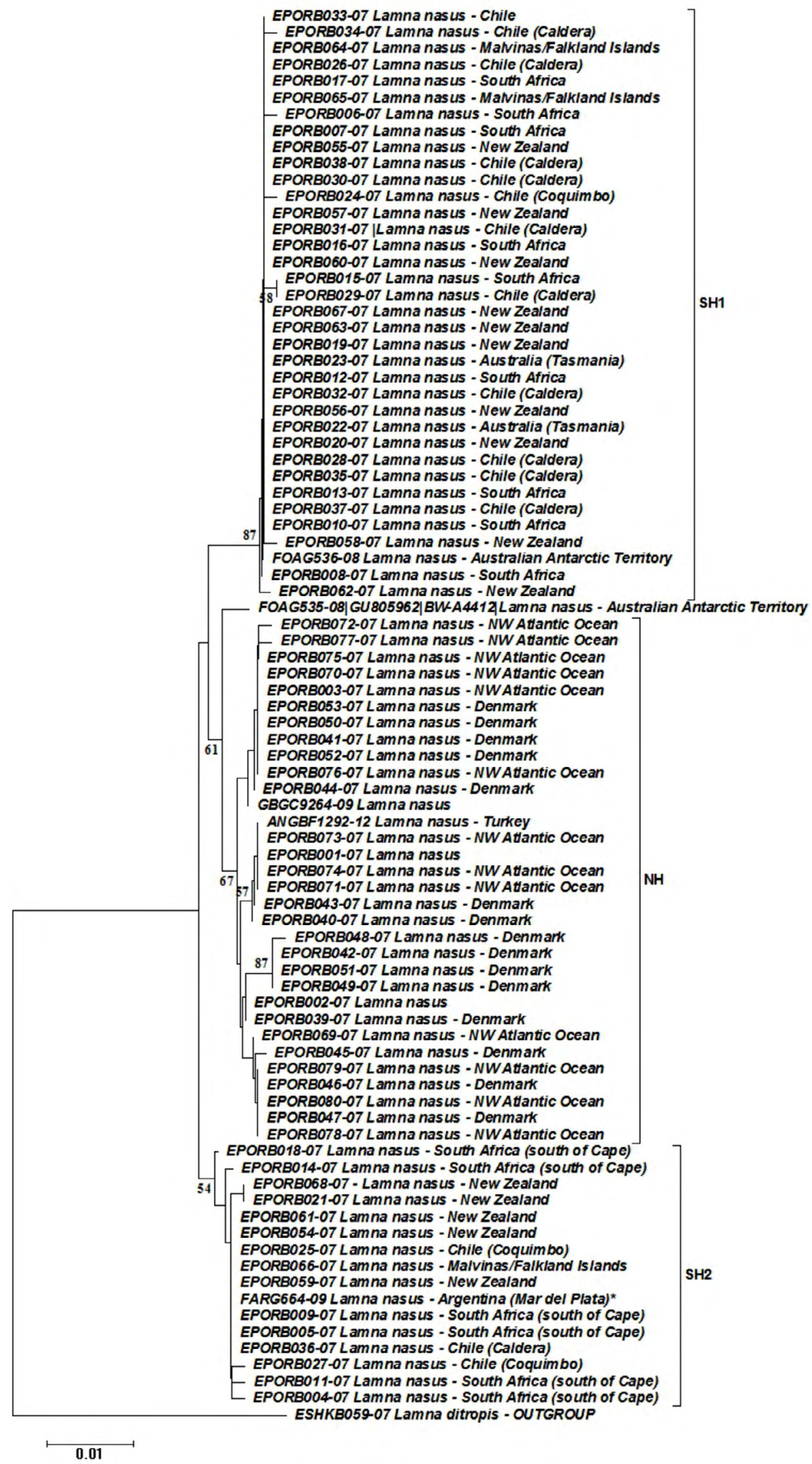

Figure 2. Neighbor-joining tree based on K2P distances of public barcode records of Lamna nasus from BOLD. Number at nodes represent bootstrap values, (only values greater than 50 are given). $\mathrm{SH}=$ southern hemisphere, $\mathrm{NH}=$ northern hemisphere. 
also found far from land in ocean basins and occasionally inshore. It has centers of distribution in the temperate North Atlantic and in a circumglobal band of temperate water in the southern Atlantic, southern Indian, southern Pacific, and Antarctic Oceans [5]. The presence of this shark in shallow waters is rare. Previous records of Lamna nasus in Argentina, except that of Lucifora and Menni [6], are from open waters deeper than $90 \mathrm{~m}$ and comprise mature specimens (from 190 to $230 \mathrm{TL}$ ) [7-10]. The coastal record of Lucifora and Menni [6] was in summer and consisted of a juvenile female. According to Jensen et al. [11] male Porbeagles mature between 160 and $190 \mathrm{~cm}$ fork length (FL) (50\% maturity length (L50) equals approximately 174 cm FL; 50\% maturity age (A50) approximately 8 years), while females mature between 205 and $230 \mathrm{~cm}$ (L50 approximately $217 \mathrm{~cm}$ FL; A50 approximately 13 years). All offshore reports of Lamna nasus in Argentina correspond to mature specimens (from 190 to $230 \mathrm{~cm} \mathrm{TL}$ ). Porbeagles are a common catch in Uruguayan longline fisheries off the Río de la Plata [12].

The Porbeagle is included in appendix II of CITES and its status at this time is Vulnerable [13]. The species is caught in longline fisheries in both the North Atlantic and the Southern Hemisphere. In the Northwest Atlantic, the Porbeagle population has been depleted to about $10 \%$ of its original abundance [14]. Information on the status of the southern population is lacking; however, the apparent slower growth of southern Porbeagles as compared to the North Atlantic population suggests an even lower resiliency to fishing pressure than the northern population [15].

This report is a case study of the utility of DNA barcoding for specimen identification, but also an example of a phylogenetic application, in this case, the genetic separation of northern and southern hemisphere populations. It also exemplifies the role of molecular analysis in contemporary systematic studies. The library of DNA sequences is constantly growing, with data from all over the world, facilitating the identification of organisms when external morphology makes difficult a correct assignment to species (e.g. part of animals, certain stages of development), and also providing supplementary phylogenetic data and even accelerating the discovery of new species.

Acknowledgements: The authors thank Ricardo Bastida who informed us about the presence of this shark on a beach. We also thank Raul Reta for providing data on water temperature and Clara Díaz de Astarloa for technical assistance in the field. We appreciate comments of anonymous reviewers and Editors that improved the previous version of the manuscript. This work represents a contribution to the South American Regional Working Group of FISH-BOL. This research was partially supported by PIP CONICET 0942 and through funding from the Canadian Barcode of Life Network from Genome Canada (through the Ontario Genomics Institute).

Conflict of interest: Authors declare nothing to disclose.

\section{References}

[1] Hajibabaei M., deWaar D.J.R., Ivanova N.V., Ratnasingham S., Dooh R.T., Kirk S.L., et al., Critical factors for assembling a high volume of DNA barcodes, Phil. Trans. R. Soc. Lond., Biol. Sci., 2005, 360, 1959-1967

[2] Ratnasingham S., Hebert P.D.N., A DNA-Based Registry for All Animal Species: The Barcode Index Number (BIN) System, PLoS ONE, 2013, 8 (8), e66213. doi:10.1371/journal.pone.0066213

[3] Kimura M., A simple method for estimating evolutionary rate of base substitutions through comparative studies of nucleotide sequences, J. Mol. Evol., 1980, 16, 111-120

[4] Tamura K., Peterson D., Peterson N., Stecher G., Nei M., Kumar S., MEGA5: Molecular Evolutionary Genetics Analysis using maximum likelihood, evolutionary distance, and maximum parsimony methods, Mol. Biol. Evol., 2011, 28, 2731-2739

[5] Compagno L.J.V., Sharks of the world. An annotated and illustrated catalogue of shark species known to date. Volume 2. Bullhead, mackerel and carpet sharks (Heterodontiformes, Lamniformes and Orectolobiformes), 2nd ed., FAO Species Catalogue for Fishery Purposes, Rome, 2001

[6] Lucifora L.O., Menni R.C., First record of a porbeagle shark, Lamna nasus, in brackish waters of Mar Chiquita lagoon, Argentina, Cybium, 1998, 22 (1), 87-88

[7] Nakaya K., Descriptive notes on a porbeagle, Lamna nasus, from Argentine waters, compared with the north Pacific salmon shark, Lamna ditropis, Bull. Fac. Fish. Hokkaido Univ., 1971, 21 (4), 269-279

[8] Menni R.C., Gosztonyi A.E., Nuevas localidades para Raja trachyderma y Lamna nasus (Chondrichthyes, Rajidae y Lamnidae), Neotropica, 1977, 23 (69), 65-68, (in Spanish)

[9] Arquez G., Castello H.P., Lichter A., Sobre la captura de un tiburón Lamna nasus en aguas patagónicas frente a Cabo Blanco (Argentina) (Lamniformes: Isuridae), Spheniscus, 1986,3, 25-29, (in Spanish)

[10] Figueroa D.E., Un nuevo registro de Lamna nasus (Bonaterre, 1788) (Elasmobranchii: Lamnidae) en proximidades de las Islas Georgias del Sur, Neotropica 1997, 43 (109-110), 112, (in Spanish)

[11] Jensen C.F., Natanson, L.J., Harold L. Pratt H.L. Jr., Kohler N.E., Campana S.E., The reproductive biology of the porbeagle shark (Lamna nasus) in the western North Atlantic Ocean, Fish. Bull., 2002, 100, 727-738

[12] Marín Y.H., Brum F., Barea L.C., Chocca J.F., Incidental catch associated with swordfish longline fisheries in the south-west Atlantic Ocean, Mar. Freshw. Res., 1998, 49, 633-639

[13] Stevens J., Fowler S.L., Soldo A., McCord M., Baum J., Acuña E., et al., Lamna nasus. In: IUCN 2013. IUCN Red List of Threatened 
Species. Version 2013.1. www.iucnredlist.org, 2006,

Downloaded on 22 January 2013

[14] Campana S., Joyce W., Marks L., Natanson L.J., Kohler N.E., Jensen C.F., et al., Population dynamics of the porbeagle in the Northwest Atlantic Ocean, N. Am. J. Fish. Manage., 2002, 22, 106-121
[15] Dulvy N.K., Baum J.K., Clarke S., Compagno L.J.V., Cortés E., Domingo A., et al., You can swim but you can't hide: the global status and conservation of oceanic pelagic sharks and rays, Aquat. Conserv: Mar. Freshw. Ecosyst., 2008, 18, 459-482 